UDC 541.128.547.264

\title{
SYNTHESIS OF TARGETED CATALYST FOR THE OXIDATIVE DEHYDRATION OF SEC-BUTANOL AND STUDY OF THE KINETICS AND MECHANISM OF THE PROCESS
}

\author{
F.A. Agayev \\ Acad. M. Nagiyev Institute of Catalysis and Inorganic Chemistry, \\ National Academy of Sciences of Azerbaijan \\ e-mail:agayev.fuad@asoiu.edu.az
}

Received 07.11.2020

Accepted 25.12.2020

\begin{abstract}
The catalytic activity of $\mathrm{CaA}$ zeolite modified with metal cations $(\mathrm{Cu}, \mathrm{Zn}, \mathrm{Pd}$ ) by means of ion exchange in the reaction of partial oxidation of sec-butanol to methyl ethyl ketone was studied at atmospheric pressure in the temperature range of $240-350^{\circ} \mathrm{C}$, space velocities 1500-4000 $\mathrm{h}^{-1}$ and partial pressures of butanol-2 $P_{B-2}=0.12-0.36 \mathrm{~atm}$, oxygen $P_{O_{2}}=0.12-0.24 \mathrm{~atm}$. It found that the metal zeolite catalyst CuZnPdCaA containing $3.0 \mathrm{wt} \% \mathrm{Cu}^{2+}, 2.0 \mathrm{wt} \% \mathrm{Zn}^{2+}$ and $0.1 \mathrm{wt} \% \mathrm{Pd}^{2+}$ exhibited the highest activity and selectivity in the reaction under consideration. Also, kinetic regularities of the reaction on the indicated catalyst were studied. On the basis of experimental data, a probable stepwise mechanism of the reaction was proposed and a theoretically substantiated kinetic model of the process developed.
\end{abstract}

Keywords: butanol-2, zeolite catalyst, oxidative dehydrogenation, kinetics, methyl ethyl ketone, ion exchange

DOI: $10.32737 / 2221-8688-2020-4-477-484$

\section{Introduction}

Methyl ethyl ketone (MEK) is used as solvent and extractant, in some cases superior to acetone, it proved not so volatile and safer in terms of fire. On industrial scale, methyl ethyl ketone is produced by oxidation of butylenes on $\mathrm{PdCl} 2$ a two-stage method which consists of hydration of n-butylene into butanol-2 with the participation of sulfuric acid as a catalyst and oxidative dehydrogenation of sec-butanol in MEK on mixed oxide catalysts $[1,2]$.

The main disadvantages of the first method are irretrievable consumption of a certain part of expensive catalyst $\mathrm{PdCl}_{2}$ and the formation of byproducts - chloroketone and crotonaldehyde. Disadvantages of the process of oxidative dehydrogenation of sec-butanol in MEK are a relatively high temperature $\left(400-500^{\circ} \mathrm{C}\right)$ and a low selectivity for methyl ethyl ketone [3-5].

For the production of methyl ethyl ketone, the method of oxidative dehydrogenation of secbutyl alcohol is used more [1]. However, due to these disadvantages, this method is characterized by low economic efficiency.

In works [6-12], we found that zeolites modified with metal cations by ion exchange exhibit high catalytic activity and selectivity in the reactions of oxidative dehydrogenation of aliphatic alcohols at relatively low temperatures (250-350 $\left.{ }^{\circ} \mathrm{C}\right)$.

Based on the analysis of the literature and the results obtained using physicochemical analysis methods, the following mechanism of methylethylketone formation can be proposed: During the absorption of secbutyl alcohol, the catalyst is protonated in the presence of Bronsted acid sites, which subsequently separates water and leads to the formation of surface alcohol. The transformation of surface alcohol into methyl ethyl ketone is possible by obtaining a surface ketone-like compound formed by combining it with surface nucleophilic oxygen. The ketone-like surface 
compound is then decomposed into methyl ethyl ketone and the catalyst is restored to its initial state.

The reaction of heterogeneous partial oxidation of aliphatic alcohols on the surface of metal zeolite catalysts occurs as a result of the interaction of these alkoxide formations with surface nucleophilic oxygen [13-15].
The aim of this work is to select an active and selective catalyst for the reaction of partial oxidation of butanol-2 into one of the most important products of the chemical industry, methyl ethyl ketone, as well as to study the kinetics and mechanism of the reaction with the participation of active metal zeolite catalyst.

\section{Experimental part}

The catalysts were prepared on the basis of $\mathrm{CaA}$ zeolite synthesized by ion exchange from $\mathrm{NaA}$. Modification of the specified zeolite with metal cations; $\mathrm{Cu}, \mathrm{Zn}$, and $\mathrm{Pd}$ were carried out by ion exchange in aqueous solutions of $\mathrm{CuCl}_{2}$, $\mathrm{ZnCl}_{2}$, and [Pd $\left.\left(\mathrm{NH}_{3}\right)_{4}\right] \mathrm{Cl}_{2}$, followed by drying $\left(80-120^{\circ} \mathrm{C}, 5 \mathrm{~h}\right)$ and calcining it in an air stream at a temperature of $300^{\circ} \mathrm{C}$, a space velocity of $2400 \mathrm{~h}^{-1}$ within 30 minutes. The amount of metal cations introduced into the zeolite composition was determined by means of mass spectrometric analysis on an ICP-MS Agilent 7700 instrument.

The experiments were carried out on a flowthrough installation directly connected to an Agilent 7820A gas-liquid chromatograph with a DB-624 column, a gas carrier (He) flow rate of $1.5 \mathrm{ml} / \mathrm{min}$ and a pressure of $7.5 \mathrm{psig}$. A Pyrex glass-based reactor was loaded with $2 \mathrm{~cm}^{3}$ of a catalyst with a particle size of $0.23-0.63 \mathrm{~mm}$, activated in a nitrogen flow at a temperature of $400^{\circ} \mathrm{C}(3 \mathrm{~h})$, then the temperature was lowered to the reaction temperature, and the reaction was fed at a certain volumetric rate mixture. The feedstock was fed using an NE-1600 microdosing device into a mixer located in a thermostated cabinet equipped with an electric heater and a fan; a stable temperature in the thermostat was maintained using a "Micromax" microelectric thermostat. The mixer also receives oxygen and a diluent gas, nitrogen. The reactor is placed in a thermostated cabinet. The reaction products at the reactor outlet were taken for analysis from a sampling loop connected to a sixway valve.

The kinetics of the reaction was studied in the temperature range of $280-340^{\circ} \mathrm{C}$, space velocities of $2000-4000 \mathrm{~h}^{-1}$, partial pressures of the $P_{B-2}$ reagents $=0.12-0.36 \mathrm{~atm}$. and $P_{O_{2}}=0.12-$ $0.24 \mathrm{~atm}$. in terms to ensure the flow reactions in the kinetic region. The purity degree of butanol-2 (B-2) grade "analytical grade" was 99.5\%.

\section{Results and discussion}

On the basis of $\mathrm{CaA}$ zeolite and metal cations $\mathrm{Cu}^{2+}, \mathrm{Zn}^{2+}$, and $\mathrm{Pd}^{2+}$, catalyst samples containing different amounts of these cations were synthesized by ion exchange. The results of testing of catalytic activity of some of these samples, as well as unmodified zeolite, $\mathrm{CaA}$ in the oxidative dehydrogenation of butanol-2 (B-2) into methyl ethyl ketone (MEK) are presented in Table 1. From the data given in Table 1 it follows that the reaction of oxidative dehydrogenation of 2-butanol to methyl ethyl ketone on these catalysts is accompanied by deep oxidation and dehydration of 2-butanol with the formation of carbon dioxide and butylenes. The yield of individual products is significantly influenced by the distribution of acid sites (when metal cations are introduced into the zeolite, the distribution of acid sites on the surface changes), as well as by the concentration and nature of the cation. From Table 1 it follows that the reaction of oxidative dehydrogenation of butanol-2 to methyl ethyl ketone on zeolite, $\mathrm{CaA}$ proceeds with a relatively low conversion (experiment No.1) which can be explained by insufficient concentration of 
dissociatively adsorbed oxygen molecules. The introduction of copper cations into the zeolite raises the yield of methyl ethyl ketone (experiments No.2-4). As the concentration of copper cations increases from $0.5 \mathrm{wt} \%$ to 3.0 $\mathrm{wt} \%$, the yield of methyl ethyl ketone significantly increases from $45.0 \%$ to $58.0 \%$, a further rise in the concentration of copper cations (up to $4.0 \mathrm{wt} \%$ ) (experiment No.5) slightly affects the IEC output. This can be explained by changes in the distribution of acid sites on the catalyst surface towards a decrease in the number of Bronsted acid sites of medium strength at relatively high concentrations of copper cations.

Table 1. Results of testing of catalytic activity of CaA zeolite (synthesized on the basis of NaA zeolite) modified with metal cations $\mathrm{Cu}^{2+}, \mathrm{Zn}^{2+}$, and $\mathrm{Pd}^{2+}$ in the oxidation of butanol-2 to methylethyl ketone at a temperature of $300^{0} \mathrm{C}$, a space velocity $\mathrm{V}=2500 \mathrm{~h}^{-1}$ and a molar ratio of reagents alcohol: $\mathrm{O}_{2}: \mathrm{N}_{2}=1$ :

0.69: 2.5

\begin{tabular}{|c|c|c|c|c|c|c|c|c|}
\hline \multirow[b]{2}{*}{ № } & \multirow[b]{2}{*}{ Zeolite } & \multicolumn{3}{|c|}{ Composition in wt.\% } & \multirow{2}{*}{$\begin{array}{c}\text { Conversion, } \\
\text { X, \% }\end{array}$} & \multicolumn{3}{|c|}{ Yield, A \% } \\
\hline & & $\mathrm{Cu}^{2+}$ & $\mathrm{Pd}^{2+}$ & $\mathrm{Zn}^{+2}$ & & $\begin{array}{c}\text { MEK, } \\
\mathrm{A}_{1}\end{array}$ & $\begin{array}{c}\text { Butylenes, } \\
\mathrm{A}_{2}\end{array}$ & $\begin{array}{c}\mathrm{CO}_{2}, \\
\mathrm{~A}_{3}\end{array}$ \\
\hline 1. & \multirow{11}{*}{$\begin{array}{c}\mathrm{CaA} \\
\text { (synthesized } \\
\text { on the basis } \\
\text { of } \mathrm{NaA} \\
\text { zeolite) }\end{array}$} & - & - & - & 18.4 & 12.1 & 6.0 & 0.3 \\
\hline 2. & & 0.5 & - & - & 48.1 & 45.0 & 2.5 & 0.6 \\
\hline 3. & & 1.0 & - & - & 58.5 & 54.6 & 3.0 & 0.9 \\
\hline 4. & & 3.0 & - & - & 63.8 & 58.0 & 4.3 & 1.5 \\
\hline 5. & & 4.0 & - & - & 64.1 & 57.6 & 4.6 & 1.9 \\
\hline 6. & & 0.5 & 0.1 & - & 80.4 & 74.7 & 3.7 & 2.0 \\
\hline 7. & & 3.0 & 0.1 & - & 84.9 & 78.8 & 4.0 & 2.1 \\
\hline 8. & & 3.0 & 0.1 & 1.0 & 88.0 & 82.4 & 3.4 & 2.2 \\
\hline 9. & & 3.0 & 0.1 & 2.0 & 91.1 & 86.9 & 2.0 & 2.2 \\
\hline 10. & & 3.0 & 0.1 & 4.0 & 87.2 & 80.0 & 4.4 & 2.8 \\
\hline 11. & & 3.0 & 1.0 & 4.0 & 95.3 & 81.8 & 9.1 & 4.4 \\
\hline
\end{tabular}

The introduction of small amounts of palladium cations $(0.1 \mathrm{wt} . \%)$ and zinc $(1.0-2.0$ wt.\%) leads to favorable distribution of acid sites on the catalyst surface in the reviewed reaction (experiments No. 6-9). In addition, these cations raise the concentration of dissociatively adsorbed oxygen molecules.

Analysis of the Table 1 data concludes that the catalyst synthesized on the basis of $\mathrm{CaA}$ zeolite by the ion exchange method, containing $3.0 \mathrm{wt} \% \mathrm{Cu}^{2+}, 2.0 \mathrm{wt} \% \mathrm{Zn}^{2+}$ and $0.1 \mathrm{wt}^{2} \% \mathrm{Pd}^{2+}$,

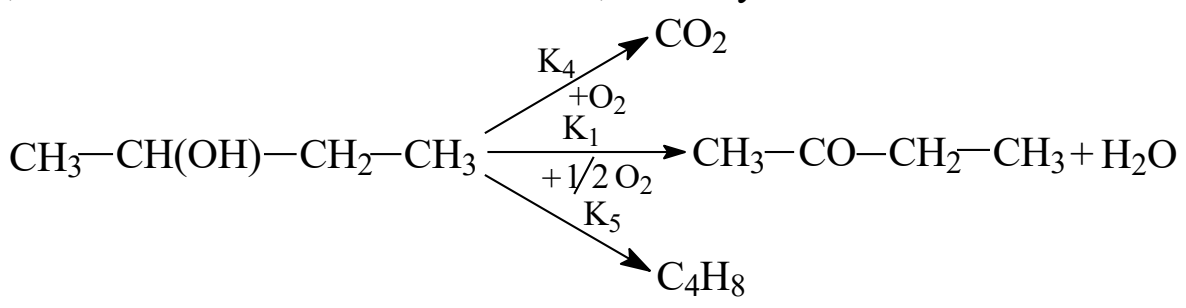


Based on the analysis of literary materials [4-6] one can suggest the following mechanism of the MEK. In the adsorption of 2-butanol is its protonation with Brønsted acid sites of the catalyst to the further elimination of water and formation of a surface alkoxide. Conversion of surface alkoxide MEK occurs when it interacts with the surface through the formation of a nucleophilic oxygen ketonopodobnogo surface compound. Then there is the collapse ketonopodobnogo surface connection to the MEK and restores the initial state of the catalyst. A simplified diagram of the staging mechanism is as follows:

$$
\begin{array}{l|l}
\mathrm{O}_{2}+2 \mathrm{Z} \stackrel{\mathrm{k}_{1}}{\longrightarrow} 2 \mathrm{ZO} & \frac{1}{2} \\
\mathrm{ZO}+\mathrm{B}-2 \stackrel{\mathrm{k}_{2}}{\longrightarrow} \mathrm{ZOB}-2 & 1 \\
\mathrm{ZOB}-2 \stackrel{\mathrm{k}_{3}}{\longrightarrow} \mathrm{Z}+\mathrm{MEK}+\mathrm{H}_{2} \mathrm{O} & 1
\end{array}
$$

All these stages are practically irreversible. expressions for stage rates: Assuming their simplicity, we find the following

$$
r_{1}=k_{1} P_{O_{2}} \theta_{1}^{2} ; r_{2}=k_{2} P_{B-2} \theta_{2} ; r_{3}=k_{3} \theta_{3}
$$

where $\theta_{1}, \theta_{2}, \theta_{3}-$ is the proportion of vacant lots modified zeolite-coated atomic oxygen molecules of 2-butanol and ketones like surface intermediates; $\mathrm{k}_{1}, \mathrm{k}_{2}, \mathrm{k}_{3}$ are rate constants of

$$
\mathrm{r}=\mathrm{r}_{1}=\mathrm{r}_{2}=\mathrm{r}_{3}
$$

respective stages of the index; $P_{\mathrm{O}_{2}}, P_{B-2}$ partial pressures of the respective index components; $r_{2}$, $\mathrm{r}_{1}, \mathrm{r}_{3}$ - speed corresponding to index steps.

In stationary conditions:

where, r-total rate of formation of MEK.

Considering these equations and the constant $\mathrm{q}_{\mathrm{i}}$ of the total formation of surface areas and the total reaction rate as a function of the concentration of reagents:

$$
\begin{array}{cc}
\theta_{1}+\theta_{2}+\theta_{3}=1 & \\
\theta_{2}=\frac{\mathrm{k}_{1} \mathrm{P}_{\mathrm{O} 2}}{\mathrm{k}_{2} \mathrm{P}_{\mathrm{B}-2}} & \theta_{3}=\frac{\mathrm{k}_{1} \mathrm{P}_{\mathrm{O} 2}}{\mathrm{k}_{3}} \theta_{1}^{2} \\
\mathrm{k}_{1} \mathrm{P}_{\mathrm{O} 2} \theta_{1}{ }^{2}=\mathrm{k}_{2} \mathrm{P}_{\mathrm{B}-2} \theta_{2} ; & \mathrm{k}_{1} \mathrm{P}_{\mathrm{O} 2} \theta_{1}{ }^{2}=\mathrm{k}_{3} \theta_{3} ;
\end{array}
$$

Substituting expression $\theta_{2}, \theta_{3}$, in the equation (4) we obtain:

$$
\left(\frac{\mathrm{k}_{1} \mathrm{P}_{\mathrm{O} 2}}{\mathrm{k}_{2} \mathrm{P}_{\mathrm{B}-2}}+\frac{\mathrm{k}_{1} \mathrm{P}_{\mathrm{O} 2}}{\mathrm{k}_{3}}\right) \theta_{1}^{2}+\theta_{1}-1=0
$$

Solving the equation (5), we obtain an

Substituting $\theta_{1}$ in equation (2) we obtain expression for $\theta_{1}$.

$$
\mathrm{r}_{\mathrm{MEK}}=\kappa_{1} \mathrm{P}_{\mathrm{O} 2}\left\{\frac{\sqrt{1+4\left(\frac{\kappa_{1} \mathrm{P}_{\mathrm{O} 2}}{2 \kappa_{2} \mathrm{P}_{\mathrm{B}-2}}+\frac{\kappa_{1} \mathrm{P}_{\mathrm{O} 2}}{2 \kappa_{3}}\right)-1}}{2\left(\frac{\kappa_{1} \mathrm{P}_{\mathrm{O} 2}}{2 \kappa_{2} \mathrm{P}_{\mathrm{B}-2}}+\frac{\kappa_{1} \mathrm{P}_{\mathrm{O} 2}}{2 \kappa_{3}}\right)}\right\}^{2}
$$


Carbon dioxide is formed by reacting weakly adsorbed molecules of 2-butanol adsorbed oxygen molecules, according to the Langmuir-

$$
r_{\mathrm{CO} 2}=\frac{\kappa_{4} \mathrm{~K}_{1} \mathrm{~K}_{2} \mathrm{P}_{\mathrm{O} 2} \mathrm{P}_{\mathrm{B}-2}}{\left(1+\mathrm{K}_{1} \mathrm{P}_{\mathrm{O} 2}+\mathrm{K}_{2} \mathrm{P}_{\mathrm{B}-2}\right)^{2}}
$$

where $\mathrm{k}_{4}$ - forming reaction rate constant of carbon dioxide, $\mathrm{K}_{1}, \mathrm{~K}_{2}$ - constant of adsorption of oxygen molecules and 2-butanol at the active centers of the catalyst surface for reaction.

$$
\mathbf{r}=\overrightarrow{\mathbf{r}}-\overline{\mathbf{r}}=\overrightarrow{\mathbf{r}}\left(1-\frac{\overline{\mathbf{r}}}{\overrightarrow{\mathbf{r}}}\right)
$$

Where

$$
1-\frac{\overrightarrow{\mathrm{r}}}{\overline{\mathrm{r}}}=1-\frac{\mathrm{P}_{\mathrm{C}_{4} \mathrm{H}_{8}} \cdot \mathrm{P}_{\mathrm{H}_{2} \mathrm{O}}}{\mathrm{K}_{\mathrm{p}} \mathrm{P}_{\mathrm{B}-2}}=\gamma
$$

$\gamma_{-}$irreversibility criterion, then:

$\overrightarrow{\mathrm{r}}$

$$
\mathbf{r}=\overrightarrow{\mathbf{r}} \gamma
$$

-can be expressed:

$$
\overrightarrow{\mathrm{r}}=\mathrm{KP}_{\mathrm{B}-2}
$$

Substituting (9) and (11) into (10) we have:

$$
\mathrm{r}=\mathrm{KP}_{\mathrm{B}-2}\left(1-\frac{\mathrm{P}_{\mathrm{C}_{4} \mathrm{H}_{8}} \cdot \mathrm{P}_{\mathrm{H}_{2} \mathrm{O}}}{\mathrm{K}_{\mathrm{p}} \mathrm{P}_{\mathrm{B}-2}}\right)=\mathrm{K}\left(\mathrm{P}_{\mathrm{B}-2}-\frac{1}{\mathrm{~K}_{\mathrm{p}}} \mathrm{P}_{\mathrm{C}_{4} \mathrm{H}_{8}} \cdot \mathrm{P}_{\mathrm{H}_{2} \mathrm{O}}\right)
$$

In view of the reaction rate of inhibition observed rate of the reaction is as follows: adsorbed molecules of alcohol and water, the

$$
\mathrm{r}_{\mathrm{C}_{4} \mathrm{H}_{8}}=\mathrm{K}_{5} \frac{\mathrm{P}_{\mathrm{B}-2}-\frac{1}{\mathrm{~K}_{\mathrm{p}}} \mathrm{P}_{\mathrm{C}_{4} \mathrm{H}_{8}} \cdot \mathrm{P}_{\mathrm{H}_{2} \mathrm{O}}}{\mathrm{K}_{3} \mathrm{P}_{\mathrm{B}-2}+\mathrm{K}_{4} \mathrm{P}_{\mathrm{H}_{2} \mathrm{O}}}
$$

where $\mathrm{K}_{\mathrm{p}}$ - equilibrium constant dehydration sec-butanol

$$
\lg K p=-A+B / T
$$


where $\mathrm{A}$ and $\mathrm{B}$ are empirical constants determined from experimental data; $K_{3}$ and $K_{4}$ are constants of equilibrium adsorption of molecules of water and alcohol in the active centers of the catalyst for dehydration reaction of 2-butanol, respectively; $\mathrm{k}_{5}$ - dehydration reaction rate constant. (To calculate the constants a and $\mathrm{K}$ in equations (6), (7) and (13) used the formula $\left.\kappa=\kappa_{0} \cdot e^{-\frac{E}{R T}}, K=K_{0} \cdot e^{\frac{Q}{R T}}\right)$.
Equations (6) and (7) and (13) form a kinetic model of the sec-butanol oxidation.

A kinetic model of the reaction is subject to statistical analysis based on kinetic data. Calculation of pre-exponential factors of reaction constants $\ln k_{i}^{0}\left(\ln K_{i}^{0}\right)$, activation energies $\left(E_{i}^{0}\right)$ and heat of adsorption $\left(Q_{i}^{0}\right)$ by means of "rolling admission" and Powell using software system "Search".

Table 3. Numerical values of kinetic model constants for oxidative conversion of sec-butanol alcohol to MEK.

\begin{tabular}{|c|c|c|c|}
\hline \multicolumn{2}{|c|}{$\ln k^{0}, \ln K^{0}$} & \multicolumn{2}{c|}{$E, Q, \mathrm{kkal} / \mathrm{mol}$} \\
\hline $\ln k_{1}^{0}$ & 7.19 & $E_{1}$ & 5.15 \\
\hline $\ln k_{2}^{0}$ & 4.03 & $E_{2}$ & 6.47 \\
\hline $\ln k_{3}^{0}$ & 7.67 & $E_{3}$ & 5.28 \\
\hline $\ln k_{4}^{0}$ & 20.91 & $E_{4}$ & 21.27 \\
\hline $\ln k_{5}^{0}$ & 9.98 & $E_{5}$ & 16.40 \\
\hline $\ln K_{1}^{0}$ & -3.21 & $\mathrm{Q}_{1}$ & 1.98 \\
\hline $\ln K_{2}^{0}$ & 4.08 & $\mathrm{Q}_{2}$ & 4.00 \\
\hline $\ln K_{3}^{0}$ & -4.67 & $\mathrm{Q}_{3}$ & 1.50 \\
\hline $\ln K_{4}^{0}$ & 4.54 & $\mathrm{Q}_{4}$ & 4.19 \\
\hline
\end{tabular}

A kinetic model of the reaction of oxidation of secondary butyl alcohol MEK adequately describes the experimental data above.
Calculations have shown that a relative error of the experimental and calculated data does not exceed $7 \%$.

\section{References}

1. Lebedev N.N. Chemistry and technology of basic organic and petrochemical synthesis. Moscow: Himiya Publ., 1975. 538 p.

2. Santaceraia E., Gelora D., Danice P. Vaporphase esterification catalyzed by decationized Y zeolites. J. Catalysis. 1983, vol., 80, p. 427.

3. Brailovsky S.M., Temkin O.N. Oxidation of alcohols on metals of the copper subgroup. Problems of kinetics and catalysis. 1985, vol. 29, pp. 146-175.
4. Balandin A.A. et al. Multiplet theory of catalysis. Moscow: MSU Publ., 1964, vol. 2, p. 53.

5. US Pat. No. 743004.1944.2.796.

6. Aliev A.M., Kasum-zade A.Yu., Matiev K.I. et al. Catalytic activity of $\mathrm{CaA}$ zeolite modified with copper, zinc and palladium cations in the oxidation reactions of butyl alcohols. Azerb. chem. journal. 2012, no. 2. pp. 9-12.

7. Patent AP I 20130021 
8. Patent AP I 20090200

9. Patent AP I 20100114

10. Shakhtakhtinsky T.N., Aliev A.M., Kuliev A.R. et al. Selection of an active catalyst and kinetics of the reaction of partial oxidation of isoamyl alcohol. Kinetics and Catalysis. 1996, vol. 37, no. 2, pp. 286-293.

11. Aliev A.M., Matiev K.I., Medzhidova S.M. Comparison of the catalytic activity of zeolites A, X, Y modified with copper and palladium cations in the oxidation reaction of isoamyl alcohol. Azerbaijan Oil Industry. 1996, no. 6, pp. 44-45.

12. Patent SU 1826925 A3 1993 (State Patent of the USSR).

13. Shakhtakhtinsky T.N., Aliev A.M., Kuliev A.R. Construction of a polyfunctional metal zeolite catalyst for a nontrivial reaction of oxidative conversion of ethyl alcohol to ethyl acetate. Dokl. Academy of Sciences of Russia. 1995, vol. 343, no. 4, pp. 496-499.

14. Aliev A.M., Medzhidova S.M., Sarydzhanov A.A. et al. Ion-exchange method for modifying zeolites with metal cations as a limiting model of the supported catalyst. Azerb. chem. journal. 2011, no. 4, pp. 9-11.

15. Aliyev A.M., Shabanova Z.A., Aliyev F.V., Guseynova A.M. Zeolites modified metal cations as catalysts in reactions of oxidation of hydrocarbons and alkyl alcohols. European Researches. Internationals Multidisciplinary Journal. 2014, vol. 82, no. 9-1, pp. 1564-1591.

\title{
BUTANOL-2 SPİRTININ OKSIDLOŞDIRİCI DEHIDROGENLOŞMə PROSESİ ÜÇÜN MəQSӘDYÖNLÜ KATALIZATORUN SINTEZI Və PROSESIN KINETIKA Və MEXANIZMININ TODQİQI
}

\author{
F.A. A ̈̆ayev \\ AMEA-nın akad. M.Nă̆ıyev adına Kataliz vo Qeyri-üzvi Kimya İnstitutu \\ AZ 1143, Bakl, H. Cavid pr., 113; \\ e-mail:agayev.fuad@asoiu.edu.az
}

İon-mübadilə üsulu ilə müxtəlif metal kationları $(\mathrm{Cu}, \mathrm{Zn}$ və $\mathrm{Pd})$ ilə modifikasiya olunmuş $\mathrm{CaA}$ seolitinin katalitik aktivliyi $240-350^{\circ} \mathrm{C}$ temperatur intervalında, $1500-4000 \mathrm{~s}^{-1}$ həcmi sürətdə və butanol-2=0.12-0.36 atm., oksigen=0.12-0.24 atm parsial təzyiqi şəraitində butanol-2-nin metiletilketona qədər qismən oksidləşməsi prosesində tədqiq olunmuşdur. Müəyyən olunmuşdur ki, tərkibində $3.0 \% \mathrm{Cu}^{2+}, 2.0 \% \mathrm{Zn}^{2+}$ və $0.1 \% \mathrm{Pd}^{2+}$ saxlayan $\mathrm{CuZnPdCaA}$ metal-seolit katalizatoru sözügedən reaksiya üçün yüksək aktivlik və selektivlik göstərir. Bu katalizator üzərində reaksiyanın getməsinin kinetik qanunauyğunluqları öyrənilmişdir. Təcrübi nəticələr əsasında reaksiyanın getməsinin mümkün mərhələli mexanizmi verilmiş və prosesin nəzəri əsaslandırılmış kinetik modeli hazırlanmışdır.

Açar sözlər: butanol-2, seolit katalizatoru, oksidləşdirici dehidrogenləşmə, kinetika, metiletilketon, ion mübadilə. 


\title{
ЦЕЛЕНАПРАВЛЕННЫЙ СИНТЕЗ КАТАЛИЗАТОРА ДЛЯ ПРОЦЕССА ОКИСЛИТЕЛЬНОГО ДЕГИДРИРОВАНИЯ ВТОР-БУТАНОЛА И ИССЛЕДОВАНИЕ КИНЕТИКИ И МЕХАНИЗМА ПРОЦЕССА
}

\author{
Ф.A. Агаев \\ Институт катализа и неорганической химии им. акад. М.Нагиева \\ Наииональной АН Азербайджана \\ AZ 1143 Баку, пр. Г. Джавида, 113; \\ e-mail: agayev.fuad@asoiu.edu.az
}

Изучена каталитическая активность цеолита СаA, модифицированного катионами металлов $(\mathrm{Cu}, \mathrm{Zn}, \mathrm{Pd})$ методом ионного обмена, в реакции парциального окисления втор-бутанола до метилэтилкетона при атмосферном давлении в интервале температур $240-350^{\circ} \mathrm{C}$, объемных скоростях $1500-4000$ ч $^{-1}$ и парциальных давлениях бутанола-2 $=0.12-0.36$ и кислорода $=0.12-0.24$ атм. Установлено, что металлцеолитный катализатор $\mathrm{CuZnPdCaA}$, содержащий 3.0 мас.\% $\mathrm{Cu}^{2+}, 2.0$ мас.\% $\mathrm{Zn}^{2+}$ и 0.1 мас.\% $\mathrm{Pd}^{2+}$, проявляет наибольшую активность и селективность в рассматриваемой реакции. Изучены кинетические закономерности реакции на указанном катализаторе. На основе экспериментальных данных предложен вероятный ступенчатый механизм реакции и разработана теоретически обоснованная кинетическая модель процесса.

Ключевые слова: бутанол-2, цеолитный катализатор, окислительное дегидрирование, кинетика, метилэтилкетон, ионный обмен. 